\title{
Diagnostic Validity of Serum and Peritoneal TNF-alpha, high sensitivity CRP and Plasma Cell-Free Nuclear DNA (ccf nDNA) as Biomarkers of Pelvic Endometriosis- A Case Control Study Ahmed F Koura, MSc*, Mohamed A Yehia, Waleed H ElTantawy, Adel S Salah El Din, Dina El-Sayed EIShennawy \\ * Departments of Obstetrics \& Gynecology and** Clinical Pathology, Faculty of Medicine, Ain Shams University.
}

\begin{abstract}
Introduction: Endometriosis is a disease defined by the presence of endometrial glands and stroma located outside the uterine cavity. These ectopic implants can be found throughout the pelvis, on and within the ovaries, abutting the uterine ligaments, occupying the rectovaginal septum, invading the intestinal serosa, and along the parietal peritoneum. Endometrial implantation at distant sites such as the pleura, lung, within surgical scars, and along the diaphragm also has been reported. ${ }^{(\mathbf{1})}$. It results often in subfertility and pain, occurs mainly in women of reproductive age (16-50 years) and has a progressive character in at least $50 \%$, but the rate and risk factors for progression are unknown. Endometriosis can be classified into four stages: minimal, mild, moderate and severe. The gold standard for the diagnosis of endometriosis is laparoscopic inspection, ideally with histological confirmation. ${ }^{(2)}$, however, is an invasive technique and should be performed only after imaging techniques prove insufficient for confident diagnosis. ${ }^{(3)}$ Lack of a non-invasive diagnostic test contributes to the long delay between onset of symptoms and diagnosis of endometriosis. ${ }^{(2)}$ Additional tools are needed for non-invasive classifications in order to reduce the number of unnecessary laparoscopies without adversely affecting outcomes. Finding specific and more sensitive biomarkers in endometriosis is critical, because endometriosis is usually diagnosed only in advanced stages, and there is a high rate of morbidity for this disease. ${ }^{(4)}$
\end{abstract}

Aim of the work: The aim of the current study is to assess the validity of serum and peritoneal high sensitivity CRP and TNF-alpha and plasma cell-free nuclear DNA (ccf nDNA) as biomarkers in early diagnosis of pelvic endometriosis.

Methods: This study was conducted at the Obstetrics \& Gynecology department, Maternity Hospital, Ain Shams University. This is a case control study of 120 women scheduled for diagnostic laparoscopy. Laparoscopy was indicated in these women whether for various causes of subfertility or for chronic pelvic pain between January 2011 and January 2012. The patients were divided into the following groups: Group I (endometriosis group/ study group) consisted of 80 patients diagnosed to have endometriosis during laparoscopy. Group I cases were subdivided into two subgroups, Group IA: consisted of 34 cases with stage 1or minimal endometriosis and Group IB: consisted of 46 cases with stage 2 or mild endometriosis. Group II (non-endometriosis group/Control group): consisted of 40 cases with no detected pelvic pathology. During the laparoscopy procedure, both peripheral venous blood and peritoneal samples were withdrawn. Serum and peritoneal levels of high sensitivity CRP and TNF-alpha as well as plasma levels of ccf nDNA were compared in both groups and in early stages (minimal and mild) of endometriosis within the study group.

Results: Serum TNF-a, serum hs-CRP and plasma ccf DNA were significantly elevated in cases compared with the control group. They were also elevated in patients with group IA and group IB as compared to control group. However, there was no statistically significant difference between cases and control group as regards peritoneal TNF-a and peritoneal hs-CRP. There was no significant difference between the group IA and group IB as regards all biomarkers.

Conclusion: Our results showed that serum TNF-alpha, serum hs-CRP and plasma ccf DNA are highly reliable biomarkers for screening and early diagnosis of endometriosis, but they can not be used to discriminate between stage I and stage II. On the other hand, peritoneal TNF-a and peritoneal hs-CRP are non reliable for early diagnosis of endometriosis and can not be used to discriminate between stage I and stage II of endometriosis.

\section{INTRODUCTION}

Endometriosis is a disease defined by the presence of endometrial glands and stroma located outside the uterine cavity. These ectopic implants can be found throughout the pelvis, on and within the ovaries, abutting the uterine ligaments, occupying the rectovaginal septum, invading the intestinal serosa, and along the parietal peritoneum. Endometrial implantation at distant sites such as the pleura, 
lung, within surgical scars, and along the diaphragm also has been reported (1).

It results often in subfertility and pain, occurs mainly in women of reproductive age (16-50 years) and has a progressive character in at least $50 \%$, but the rate and risk factors for progression are unknown. Endometriosis can be classified into four stages: minimal, mild, moderate and severe. The gold standard for the diagnosis of endometriosis is laparoscopic inspection, ideally with histological confirmation (2), however, is an invasive technique and should be performed only after imaging techniques prove insufficient for confident diagnosis (3).

Lack of a non-invasive diagnostic test contributes to the long delay between onset of symptoms and diagnosis of endometriosis. (2) Additional tools are needed for non-invasive classifications in order to reduce the number of unnecessary laparoscopies without adversely affecting outcomes. Finding specific and more sensitive biomarkers in endometriosis is critical, because endometriosis is usually diagnosed only in advanced stages, and there is a high rate of morbidity for this disease (4).

Development of a non-invasive diagnostic test for endometriosis would have a groundbreaking impact on the patients' quality of life, on the efficacy of available treatment as well as on the cost of endometriosis (2).

A non-invasive diagnostic test could be developed in circulation or menstrual fluid based on the pathology of endometriosis, such as immune function, cell-death event and, or inflammatory reactions in the patients with endometriosis (4).

TNF-a, a secretory product of activated macrophages, is a potent inducer of new blood vessel growth, besides stimulating the proliferation of endometriotic stromal cells (5).

Serum C-reactive protein (CRP), which is a protein of the acute inflammatory phase, is widely used as a marker of ongoing inflammation in clinical practice. (6)

The discovery of circulating cell-free (ccf) DNA in circulation has opened up the possibilities of non-invasive diagnosis and monitoring of a wide variety of inflammatory conditions, such as systemic lupus erythematosus and rheumatoid arthritis. (7)

\section{THE AIM OF THE WORK}

The aim of the current study is to assess the validity of serum and peritoneal high sensitivity CRP and TNF-alpha and plasma cell-free nuclear DNA (ccf nDNA) as biomarkers in early diagnosis of pelvic endometriosis.

\section{METHODS}

This is a case control study of 120 women scheduled for diagnostic laparoscopy at Ain Shams University Maternity Hospital. Laparoscopy is indicated in these women whether for various causes of subfertility or for chronic pelvic pain between January 2011 and January 2012.

\section{Inclusion criteria were:}

reproductive age (between 23 and 43 years).

regular menstrual cycles.

\section{Exclusion criteria were:}

-age $>45$ years

-patients with known history of any malignancy

-patients with overt stage 3 or 4 endometriosis -patients with overt infection.

The purposes and procedures of the study was explained to all eligible women before recruitment in the study. Included women were asked to sign an informed consent before participating in the study.

These patients were subjected to the following: full history, general and abdominal examination, local pelvic examination and laparoscopic visualization of presence or absence of endometriosis.

All laparoscopy procedures were performed in the proliferative phase of the cycle. The abdomen and pelvis were systematically inspected for signs of endometriosis. Women who showed positive signs for minimal or mild endometriosis (grade 1 and 2) were staged according to the ASRM classification (1997), and categorized as group I (Study or Endometriosis Group). Group I cases were subdivided into two subgroups: Group IA $\mathrm{s}$ with stage 1or minimal endometriosis and Group IB with stage 2 or mild endometriosis.

These women with laparoscopically diagnosed endometriosis had a biopsy from the endometriotic lesions for Histopathological confirmation.All other women who were laparoscopically free of signs of endometriosis were categorized as group II (Control Group).

During the laparoscopy procedure, both peripheral venous blood and peritoneal samples were withdrawn. Concentration of TNF-alpha was measured by ELISA using Orgenium Laboratories' human TNF-alpha kits .Concentration of high sensitivity CRP was measured by automated assays.DNA was 
extracted using the commercially available kits for real time multiplex PCR in Egypt.

Serum and peritoneal levels of high sensitivity CRP and TNF-alpha as well as plasma levels of ccf nDNA were compared in both groups and in early stages (minimal and mild) of endometriosis within the study group.

\section{RESUltS}

The mean age among cases; Group I patients was 27.7 yrs \pm 3.76. The youngest patient was 21 years old and the oldest was 39 years old. The mean age for cases with stage 1 endometriosis was $24.4 \pm 3.18$, for cases with stage 2 endometriosis was $27.8 \pm 4$.16.The mean age for control group; Group II was 30.1 \pm 7.42 .

The mean Body mass Index (BMI) among cases; Group I patients was 26.33 3.39. The mean BMI for cases with stage 1 endometriosis was $25.82 \pm 2.96$, for cases with stage 2 endometriosis was $26.71 \pm 3.567$ .The mean BMI for control group; Group II was $26.28 \pm 3.83$.

Tables 1-4 show description of personal and lab data among cases (Group I endometriosis), Group I A; Stage 1 Endometriosis, Group I b; stage 2 Endometriosis and among control group (Group II)

Table (1): Description of personal and lab data among cases; Group I endometriosis:

\begin{tabular}{|c|c|c|c|c|}
\hline Cases & Minimum & Maximum & Mean & \pm SD \\
\hline Age (years) & 21.00 & 39.00 & 27.70 & 3.76 \\
\hline BMI (kg/m2) & 20.34 & 32.45 & 26.33 & 3.39 \\
\hline $\begin{array}{c}\text { Serum TNF } \\
(\mathrm{pg} / \mathrm{ml})\end{array}$ & 100.00 & 491.00 & 285.23 & 107.01 \\
\hline $\begin{array}{c}\text { Peritoneal TNF } \\
(\mathrm{pg} / \mathrm{ml})\end{array}$ & 110.00 & 988.00 & 158.51 & 39.60 \\
\hline $\begin{array}{c}\text { Serum hsCRP } \\
(\mathrm{ng} / \mathrm{ml})\end{array}$ & 1.00 & 8.50 & 2.10 & 1.86 \\
\hline $\begin{array}{c}\text { Peritoneal hsCRP } \\
(\mathrm{ng} / \mathrm{ml})\end{array}$ & 0.80 & 2.50 & 0.86 & 0.38 \\
\hline $\begin{array}{c}\text { Plasma ccf. DNA } \\
\text { (genome equivalent/ml) }\end{array}$ & 3600.00 & 93000.00 & 25196.38 & 20443.18 \\
\hline
\end{tabular}

Table (2): Description of personal and lab data among Group I A; Stage 1 Endometriosis

\begin{tabular}{|c|c|c|c|c|}
\hline & Minimum & Maximum & Mean & \pm SD \\
\hline Age (years) & 22.00 & 39.00 & 27.47 & 3.18 \\
\hline BMI (kg/m2) & 21.58 & 31.26 & 25.82 & 2.96 \\
\hline $\begin{array}{c}\text { Serum TNF } \\
(\mathrm{pg} / \mathrm{ml})\end{array}$ & 100.00 & 350.00 & 147.38 & 65.69 \\
\hline $\begin{array}{c}\text { Peritoneal TNF } \\
(\mathrm{pg} / \mathrm{ml})\end{array}$ & 110.00 & 461.00 & 151.32 & 110.28 \\
\hline $\begin{array}{c}\text { Serum hsCRP } \\
(\mathrm{ng} / \mathrm{ml})\end{array}$ & 1.00 & 6.00 & 2.08 & 1.31 \\
\hline $\begin{array}{c}\text { Peritoneal hsCRP } \\
(\mathrm{ng} / \mathrm{ml})\end{array}$ & 0.80 & 2.50 & 0.78 & 0.40 \\
\hline $\begin{array}{c}\text { Plasma ccf. DNA } \\
\text { (genome equivalent/ml) }\end{array}$ & 3600.00 & 34000.00 & 5944.71 & 2192.97 \\
\hline
\end{tabular}

Table (3): Description of personal and lab data among Group I B; Stage 2 endometriosis 
Diagnostic Validity of Serum and Peritoneal TNF-alpha...

\begin{tabular}{|c|c|c|c|c|}
\hline & Minimum & Maximum & Mean & \pm SD \\
\hline Age (years) & 21.00 & 39.00 & 27.87 & 4.16 \\
\hline BMI(kg/m2) & 20.34 & 32.45 & 26.71 & 3.67 \\
\hline $\begin{array}{c}\text { Serum TNF } \\
(\mathrm{pg} / \mathrm{ml})\end{array}$ & 190.00 & 491.00 & 242.76 & 89.11 \\
\hline $\begin{array}{c}\text { Peritoneal TNF } \\
(\mathrm{pg} / \mathrm{ml})\end{array}$ & 190.00 & 988.00 & 177.35 & 95.74 \\
\hline $\begin{array}{c}\text { Serum hsCRP } \\
(\mathrm{ng} / \mathrm{ml})\end{array}$ & 1.60 & 8.50 & 2.10 & 2.06 \\
\hline $\begin{array}{c}\text { Peritoneal hsCRP } \\
(\mathrm{ng} / \mathrm{ml})\end{array}$ & 1.20 & 2.50 & 0.83 & 0.36 \\
\hline $\begin{array}{c}\text { Plasma ccf. DNA } \\
\text { (genome equivalent/ml) }\end{array}$ & 3600.00 & 93000.00 & 7108.48 & 2975.59 \\
\hline
\end{tabular}

Table (4): Description of personal and lab data among controls; Group II

\begin{tabular}{|c|c|c|c|c|}
\hline Control & Minimum & Maximum & Mean & \pm SD \\
\hline Age (years) & 22.00 & 44.00 & 30.10 & 7.42 \\
\hline BMI (kg/m2) & 21.02 & 31.44 & 26.28 & 3.83 \\
\hline $\begin{array}{c}\text { Serum TNF } \\
(\mathrm{pg} / \mathrm{ml})\end{array}$ & 50.00 & 200.00 & 102.75 & 36.71 \\
\hline $\begin{array}{c}\text { Peritoneal TNF } \\
(\mathrm{pg} / \mathrm{ml})\end{array}$ & 80.00 & 300.00 & 146.25 & 43.70 \\
\hline $\begin{array}{c}\text { Serum hsCRP } \\
(\mathrm{ng} / \mathrm{ml})\end{array}$ & 0.40 & 2.99 & 1.27 & 0.60 \\
\hline $\begin{array}{c}\text { Peritoneal hsCRP } \\
\text { (ng/ml) }\end{array}$ & 0.10 & 1.50 & 0.74 & 0.40 \\
\hline $\begin{array}{c}\text { Plasma ccf. DNA } \\
\text { (genome equivalent/ml) }\end{array}$ & 1090.00 & 9180.00 & 4903.00 & 2172.44 \\
\hline
\end{tabular}

Student $\mathbf{T}$ Test was used to assess the statistical significance of the difference between two study group means.

- P- value: level of significance

$-\mathrm{P}>0.05$ : Non significant (NS).

$-\mathrm{P}<0.05$ : Significant $(\mathrm{S})$.

$-\mathrm{P}<0.01$ : Highly significant (HS)

Table (5): Comparison between cases (Group I) and controls (Group II) as regard personal and lab findings

\begin{tabular}{|c|c|c|c|c|c|c|c|}
\hline \multirow[b]{2}{*}{ Parameters } & \multicolumn{2}{|l|}{ Patients } & \multicolumn{2}{|l|}{ Control } & \multicolumn{2}{|l|}{ t-test } & \multirow[t]{2}{*}{ sig } \\
\hline & Mean & $\pm \mathrm{SD}$ & Mean & \pm SD & $\mathrm{t}$ & $\mathrm{p}$-value & \\
\hline Age (years) & 27.70 & 3.76 & 30.10 & 7.42 & -2.356 & 0.060 & NS \\
\hline BMI $(\mathrm{kg} / \mathrm{m} 2)$ & 26.33 & 3.39 & 26.28 & 3.83 & 0.072 & 0.090 & $\mathrm{NS}$ \\
\hline $\begin{array}{l}\text { Serum TNF } \\
(\mathrm{pg} / \mathrm{ml})\end{array}$ & 285.23 & 107.01 & 102.75 & 36.71 & 10.462 & $<0.001$ & $\mathrm{HS}$ \\
\hline $\begin{array}{l}\text { Peritoneal TNF } \\
(\mathrm{pg} / \mathrm{ml})\end{array}$ & 158.51 & 39.60 & 146.25 & 43.70 & 1.544 & 0.125 & $\mathrm{NS}$ \\
\hline $\begin{array}{c}\text { Serum hsCRP } \\
(\mathrm{ng} / \mathrm{ml})\end{array}$ & 2.10 & 1.86 & 1.27 & 0.60 & 2.747 & 0.021 & $S$ \\
\hline $\begin{array}{l}\text { Peritoneal hsCRP } \\
(\mathrm{ng} / \mathrm{ml})\end{array}$ & 0.86 & 0.38 & 0.74 & 0.40 & 1.602 & 0.111 & NS \\
\hline $\begin{array}{c}\text { Plasma ccf. DNA } \\
\text { (genome } \\
\text { equivalent/ml) }\end{array}$ & 25196.38 & 20443.18 & 4903.00 & 2172.44 & 6.248 & $<0.001$ & HS \\
\hline
\end{tabular}




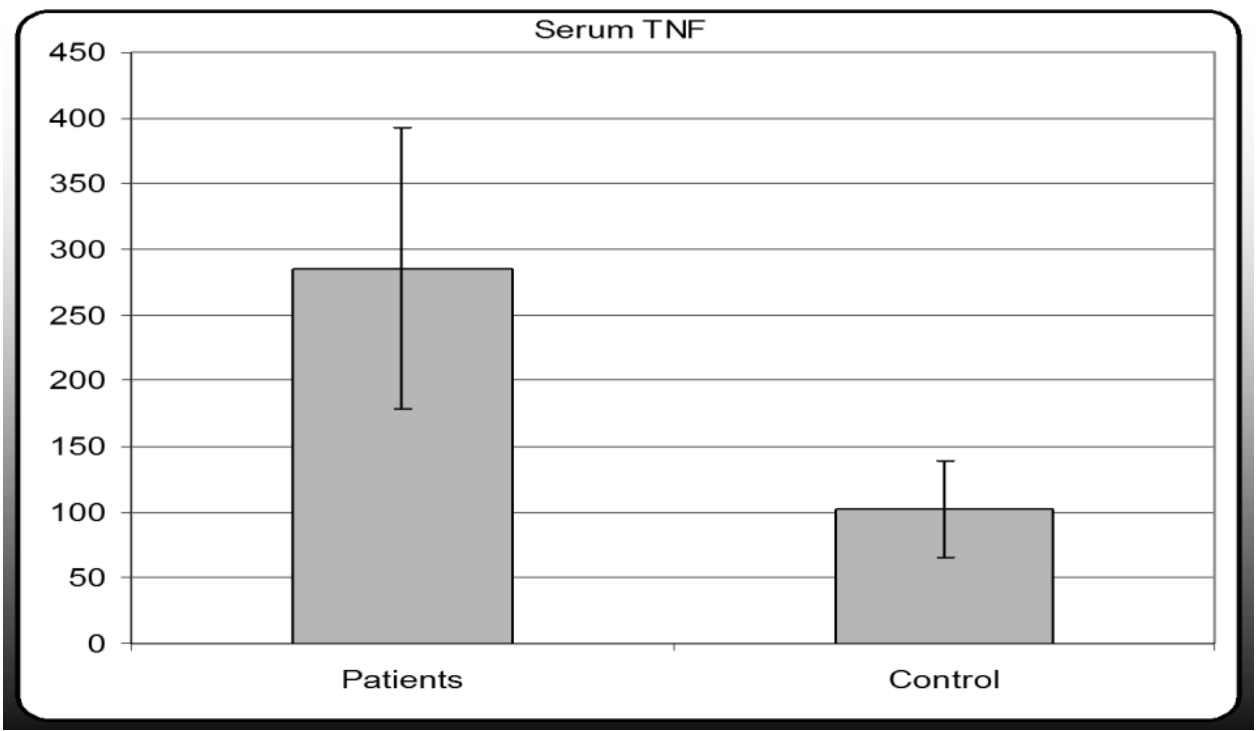

Fig 1: Bar graph shows the difference between Serum TNF among Cases and Control Group.

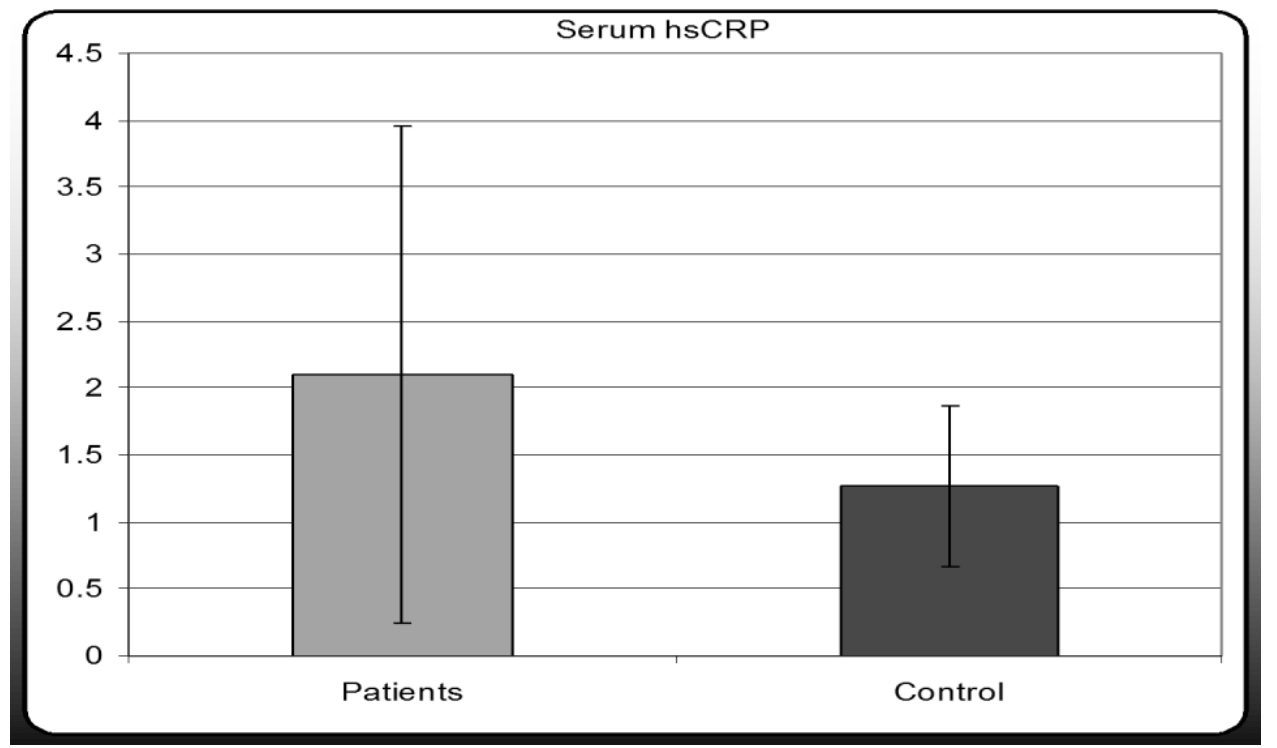

Fig 2: Bar graph shows the difference between serum hs-CRP among Cases and Control Group.

Table (6): Comparison between Group IA and controls as regard personal and lab findings

\begin{tabular}{|c|c|c|c|c|c|c|c|}
\hline \multirow{2}{*}{ Parameters } & \multicolumn{2}{|c|}{ Control } & \multicolumn{2}{c|}{ Minimal } & \multicolumn{2}{|c|}{ t-test } & sig \\
\cline { 2 - 8 } & Mean & \pm SD & Mean & \pm SD & $\mathrm{t}$ & $\mathrm{p}$-value & \\
\hline Age (years) & 30.10 & 7.42 & 27.47 & 3.18 & 1.920 & 0.059 & $\mathrm{NS}$ \\
\hline BMI (kg/m2) & 26.28 & 3.83 & 25.82 & 2.96 & 0.575 & 0.567 & $\mathrm{NS}$ \\
\hline $\begin{array}{c}\text { Serum TNF } \\
(\mathrm{pg} / \mathrm{ml})\end{array}$ & 102.75 & 36.71 & 147.38 & 65.69 & -3.322 & 0.023 & $\mathrm{~S}$ \\
\hline $\begin{array}{c}\text { Peritoneal TNF } \\
(\mathrm{pg} / \mathrm{ml})\end{array}$ & 146.25 & 43.70 & 151.32 & 70.28 & -0.382 & 0.703 & $\mathrm{NS}$ \\
\hline $\begin{array}{c}\text { Serum hsCRP } \\
(\mathrm{ng} / \mathrm{ml})\end{array}$ & 1.27 & 0.60 & 2.08 & 1.31 & -7.808 & 0.044 & $\mathrm{~S}$ \\
\hline $\begin{array}{c}\text { Peritoneal hsCRP } \\
(\mathrm{ng} / \mathrm{ml})\end{array}$ & 0.74 & 0.40 & 0.78 & 0.40 & -0.435 & 0.664 & $\mathrm{NS}$ \\
\hline $\begin{array}{c}\text { Plasma ccf. DNA } \\
\text { (genome equivalent/ml) }\end{array}$ & 4903.00 & 2172.44 & 5944.71 & 2192.97 & -2.047 & 0.044 & $\mathrm{~S}$ \\
\hline
\end{tabular}


Diagnostic Validity of Serum and Peritoneal TNF-alpha...

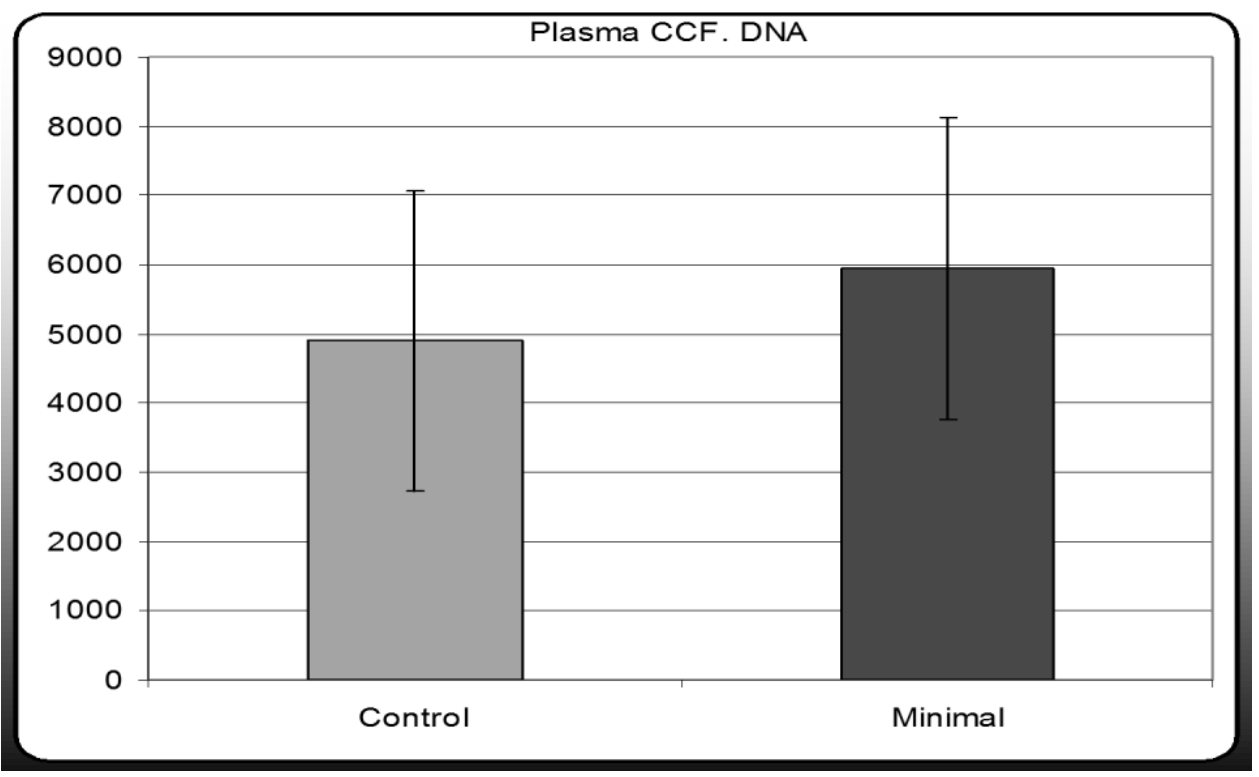

Fig 3: Bar graph shows the difference between Plasma ccf DNA among Group IA (Stage 1 endometriosis) and Control Group.

Table (7): Comparison between Group IB and controls as regard personal and lab findings

\begin{tabular}{|c|c|c|c|c|c|c|c|}
\hline \multirow[b]{2}{*}{ Parameters } & \multicolumn{2}{|c|}{ Control } & \multicolumn{2}{|c|}{ Mild } & \multicolumn{2}{|c|}{ t-test } & sig \\
\hline & Mean & $\pm \mathrm{SD}$ & Mean & $\pm \mathrm{SD}$ & $\mathrm{t}$ & p-value & \\
\hline Age (years) & 30.10 & 7.42 & 27.87 & 4.16 & 1.748 & 0.084 & NS \\
\hline BMI (kg/m2) & 26.28 & 3.83 & 26.71 & 3.67 & -0.530 & 0.598 & NS \\
\hline $\begin{array}{l}\text { Serum TNF } \\
\quad(\mathrm{pg} / \mathrm{ml})\end{array}$ & 102.75 & 36.71 & 242.76 & 89.11 & -15.893 & $<0.001$ & HS \\
\hline $\begin{array}{l}\text { Peritoneal TNF } \\
\quad(\mathrm{pg} / \mathrm{ml})\end{array}$ & 146.25 & 43.70 & 177.35 & 95.74 & -1.852 & 0.068 & NS \\
\hline $\begin{array}{l}\text { Serum hsCRP } \\
(\mathrm{ng} / \mathrm{ml})\end{array}$ & 1.27 & 0.60 & 2.10 & 2.06 & -2.438 & 0.017 & S \\
\hline $\begin{array}{l}\text { Peritoneal hsCRP } \\
\text { (ng/ml) }\end{array}$ & 0.74 & 0.40 & 0.83 & 0.36 & -0.961 & 0.339 & NS \\
\hline $\begin{array}{c}\text { Plasma ccf. DNA } \\
\text { (genome equivalent } / \mathrm{ml} \text { ) }\end{array}$ & 4903.00 & 2172.44 & 7108.48 & 2975.59 & -2.178 & 0.013 & S \\
\hline
\end{tabular}




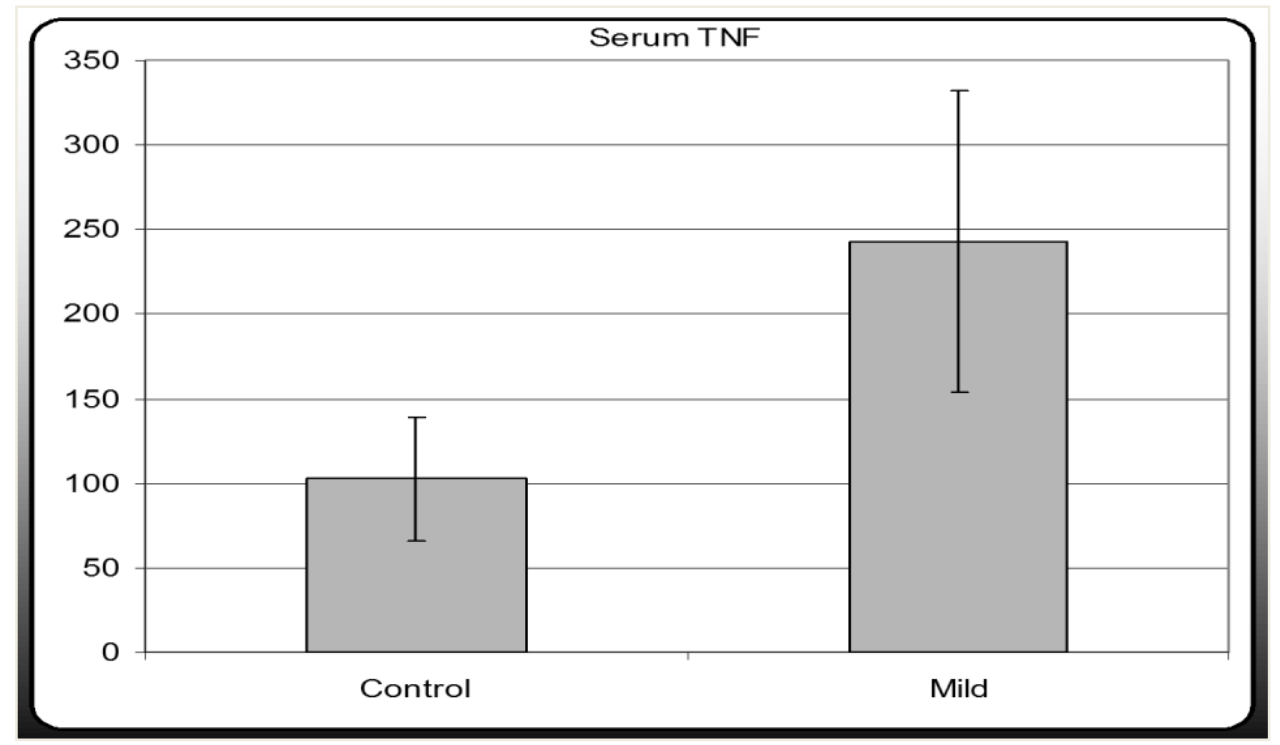

Fig 4 :Bar graph shows the difference between Serum TNF among Group IB (Stage 2 endometriosis) and Control Group.

Table (8): Comparison between minimal and mild cases as regard personal and lab findings

\begin{tabular}{|c|c|c|c|c|c|c|c|}
\hline \multirow{2}{*}{ Parameters } & \multicolumn{2}{|c|}{ Minimal } & \multicolumn{2}{c|}{ Mild } & \multicolumn{2}{c|}{ t-test } & sig \\
\cline { 2 - 8 } & Mean & \pm SD & Mean & \pm SD & $\mathrm{t}$ & $\mathrm{p}$-value & \\
\hline Age (years) & 27.47 & 3.18 & 27.87 & 4.16 & -0.467 & 0.642 & $\mathrm{NS}$ \\
\hline BMI (kg/m2) & 25.82 & 2.96 & 26.71 & 3.67 & -1.166 & 0.247 & $\mathrm{NS}$ \\
\hline $\begin{array}{c}\text { Serum TNF } \\
(\mathrm{pg} / \mathrm{ml})\end{array}$ & 147.38 & 65.69 & 242.76 & 89.11 & -5.341 & 0.051 & $\mathrm{NS}$ \\
\hline $\begin{array}{c}\text { Peritoneal TNF } \\
(\mathrm{pg} / \mathrm{ml})\end{array}$ & 151.32 & 110.28 & 177.35 & 95.74 & -1.127 & 0.263 & $\mathrm{NS}$ \\
\hline $\begin{array}{c}\text { Serum hsCRP } \\
(\mathrm{ng} / \mathrm{ml})\end{array}$ & 2.08 & 1.31 & 2.10 & 2.06 & 0.050 & 0.960 & $\mathrm{NS}$ \\
\hline $\begin{array}{c}\text { Peritoneal hsCRP } \\
(\mathrm{ng} / \mathrm{ml})\end{array}$ & 0.78 & 0.40 & 0.83 & 0.36 & -0.586 & 0.559 & $\mathrm{NS}$ \\
\hline $\begin{array}{c}\text { Plasma ccf. DNA } \\
\text { (genome equivalent/ml) }\end{array}$ & 5944.71 & 2192.97 & 7108.48 & 2975.59 & -1.925 & 0.057 & $\mathrm{NS}$ \\
\hline
\end{tabular}

Table (9): ROC Curve to discriminate between cases and controls using tested markers

\begin{tabular}{|c|c|c|c|c|c|c|c|c|c|}
\hline $\begin{array}{c}\text { Test markers } \\
\text { (cutoff points) }\end{array}$ & AUC & \multicolumn{2}{|c|}{$(\mathbf{9 5 \%}$ CI) } & Sensitivity & Specificity & PPV & NPV & P & Sig \\
\hline $\begin{array}{c}\text { Serum TNF } \\
\geq 165\end{array}$ & 0.88 & 80.3 & 98.5 & 95.0 & 86.2 & 77.6 & 97.2 & 0.026 & $\mathrm{~S}$ \\
\hline $\begin{array}{c}\text { Peritoneal } \\
\text { TNF } \geq 180\end{array}$ & 0.92 & 83.0 & 99.2 & 87.0 & 76.7 & 80.9 & 97.3 & 0.050 & $\mathrm{NS}$ \\
\hline $\begin{array}{c}\text { Serum } \\
\text { hSCRP } \geq 1.5\end{array}$ & 0.83 & 87.7 & 97.3 & 85.0 & 93.7 & 87.2 & 92.6 & 0.021 & $\mathrm{~S}$ \\
\hline $\begin{array}{c}\text { Peritoneal } \\
\text { hSCRP } \geq 1.00\end{array}$ & 0.91 & 61.5 & 89.1 & 77.5 & 98.7 & 96.9 & 89.8 & 0.033 & $\mathrm{~S}$ \\
\hline $\begin{array}{c}\text { Plasma ccf. } \\
\text { DNA } \geq 5950 .\end{array}$ & 0.89 & 86.8 & 99.6 & 97.5 & 71.2 & 62.9 & 98.3 & $<0.001$ & $\mathrm{HS}$ \\
\hline
\end{tabular}




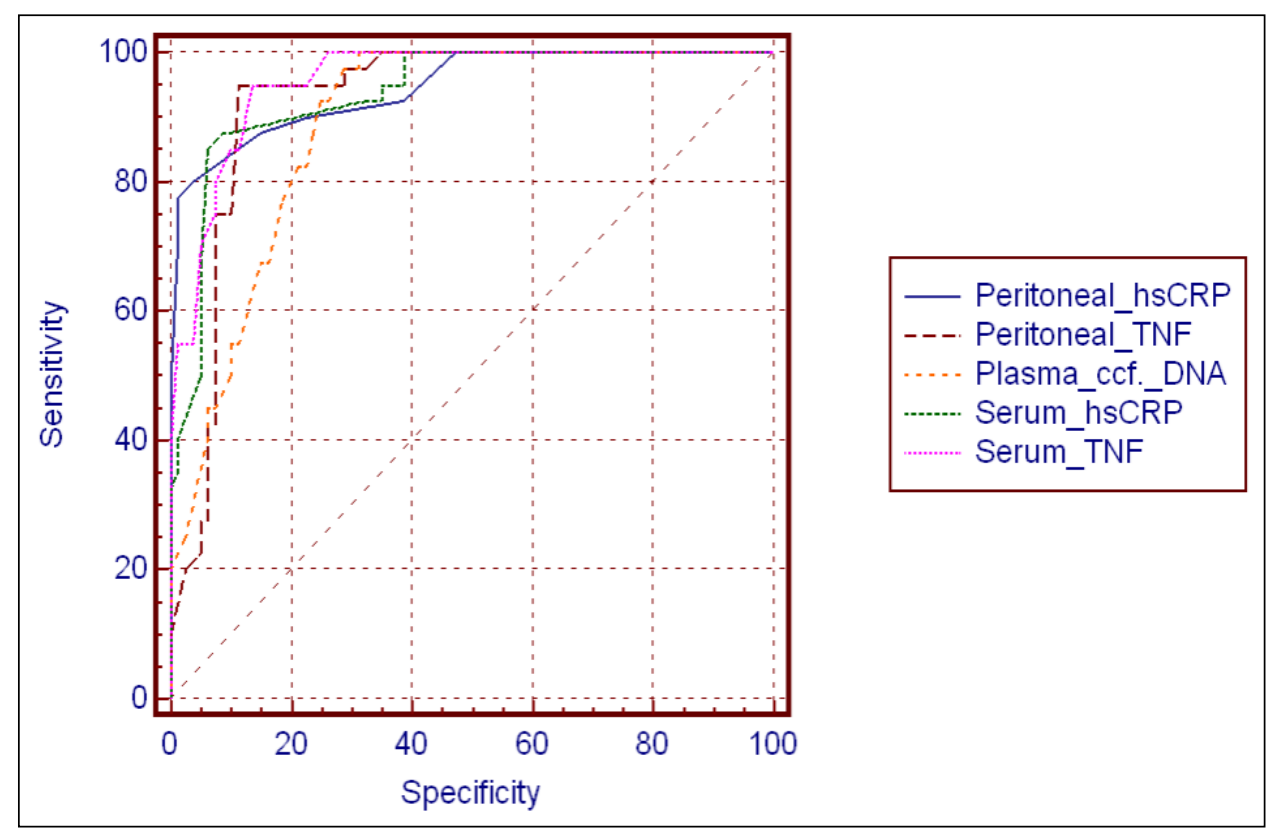

Fig 5: ROC curve for Serum TNF, Peritoneal TNF, serum hsCRP, peritoneal hsCRP and plasma ccf DNA to discriminate between cases and controls.

Table (10):ROC Curve to discriminate between minimal and mild cases using tested markers

\begin{tabular}{|c|c|c|c|c|c|c|c|c|c|}
\hline $\begin{array}{c}\text { Test markers } \\
\text { (cutoff points) }\end{array}$ & AUC & \multicolumn{2}{|c|}{$\mathbf{( 9 5 \%}$ CI) } & Sensitivity & Specificity & PPV & NPV & P & Sig \\
\hline $\begin{array}{c}\text { Serum TNF } \\
\geq 286\end{array}$ & 0.87 & 0.784 & 0.940 & 76.1 & 82.4 & 85.4 & 71.8 & 0.074 & NS \\
\hline $\begin{array}{c}\text { Peritoneal } \\
\text { TNF } \geq 426\end{array}$ & 0.86 & 0.767 & 0.929 & 71.7 & 84.1 & 97.3 & 71.1 & 0.063 & NS \\
\hline $\begin{array}{c}\text { Serum } \\
\text { hsCRP } \geq 4.6\end{array}$ & 0.65 & 0.542 & 0.759 & 47.8 & 91.2 & 88.0 & 56.4 & 0.068 & NS \\
\hline $\begin{array}{c}\text { Peritoneal } \\
\text { hsCRP } \geq 1.2\end{array}$ & 0.57 & 0.455 & 0.681 & 91.3 & 23.5 & 61.8 & 66.7 & 0.282 & NS \\
\hline $\begin{array}{c}\text { Plasma ccf. } \\
\text { DNA } \geq 22900\end{array}$ & 0.85 & 0.762 & 0.926 & 69.6 & 97.1 & 97.0 & 70.2 & 0.024 & S \\
\hline
\end{tabular}

Fig 6: ROC curve for Serum TNF, Peritoneal TNF, serum hsCRP, peritoneal hsCRP and plasma ccf DNA to discriminate cases with stage 1 from cases with stage 2 . 


\section{DISCUSSION}

Endometriosis is estimated to affect $10-15 \%$ of women of reproductive age and is characterized by the presence of functional endometrial glands and stroma outside the uterine cavity, resulting in chronic pelvic pain, dysmenorrhoea, dyspareunia and infertility; this leads to a considerable burden in terms of health care costs and the quality of life (8)

The diagnosis of endometriosis can be suspected in women with pelvic pain and/or subfertility, although endometriosis may be completely asymptomatic (9).Clinical detection of abdominal or pelvic pain can be suggestive of endometriosis. Vaginal ultrasound is an adequate diagnostic method to detect ovarian endometriotic cysts and deeply infiltrative endometriotic noduli, but does not rule out peritoneal endometriosis or endometriosis-associated adhesions. The gold standard for the diagnosis of endometriosis is laparoscopic inspection, ideally with histological confirmation (2)

Because laparoscopy is an invasive procedure, the diagnosis of endometriosis is often delayed for an average of 11.7 years in patients with pelvic pain and for 3.5 years in patients with infertility (10). It was found that the younger the patient is at onset of the symptoms, the longer it takes before an endometriosis diagnosis is made (11). This delay may result in social and/or work-related problems for the patient, in addition to increased anxiety and fear of having a more serious condition (10)

Development of a non-invasive diagnostic test for endometriosis would have a groundbreaking impact on the patients' quality of life, on the efficacy of available treatment as well as on the cost of endometriosis (2).

The aim of our study was to assess the validity of serum and peritoneal high sensitivity CRP and TNF- alpha and plasma cell-free nuclear DNA (ccf nDNA) as biomarkers in early diagnosis of pelvic endometriosis.

In our study, serum TNF-levels were significantly elevated in women with endometriosis compared with controls. ( $\mathrm{P}<$ 0.001) Serum TNF-a levels were also significantly elevated in women with stage 1 and stage 2 endometriosis compared with controls. Comparing serum TNF-levels between women with stage 1 and stage 2 endometriosis, there was no statistically significant difference $(\mathrm{P}>0.05)$.

Foda and Abdel Aal (12) performed a study on a total of 95 women who underwent laparoscopy were divided into two groups: control cases (30 cases) with no pathologic findings; and endometriosis patients (65 cases);subdivided into stages 1-2 or minimalmild (MM) and stages 3-4 or moderate-severe (MS) cases. They measured serum and peritoneal levels of IL-6, CA-125, TNF-a, HsCRP and VEGF. In agreement with our results, Serum TNF-a levels were significantly higher in women with endometriosis when compared with the controls $(\mathrm{P}<0.001)$. Serum TNF-a were significantly elevated in women with MM endometriosis when compared with the control cases $(\mathrm{P}<0.001)$ and with $\mathrm{MS}$ endometriosis $(\mathrm{P}<0.006 \& \mathrm{P}<0.03$ respectively).

In our study, using ROC curve analysis, Serum TNF had a cut off point of $165 \mathrm{pg} / \mathrm{ml}$ to discriminate cases from controls, with a sensitivity of $95 \%$, specificity of 86.2 $\%$ positive predictive value of 77.6, negative predictive value of 97.2 with diagnostic AUC of 0.88 . Serum TNF had a cut off point of 286 $\mathrm{pg} / \mathrm{ml}$ to discriminate cases with stage 1 from cases with stage 2 , with a sensitivity of $76.1 \%$, specificity of $82.4 \%$ positive predictive value of 85.4 , negative predictive value of 71.8 with diagnostic AUC of 0.87 .

By using ROC curve analysis in the study by Foda and Abdel Aal (12), the serum TNF-a optimal threshold value of $>12.45$ $\mathrm{pg} / \mathrm{ml}$ was found to be able to diagnose endometriosis with a sensitivity, specificity, diagnostic accuracy \& AUC of $89.23 \%$, $86.87 \%, 86.67 \%$ \& 0.89 respectively.

In the current study, Peritoneal TNFa levels were not significantly elevated in women with endometriosis compared with controls. Peritoneal TNF-a levels were also non significantly elevated in women with stage 1 and stage 2 endometriosis compared with controls. Comparing peritoneal TNF-a levels between women with stage 1 and stage 2 endometriosis, there was also a no significant difference $\mathrm{P}>0.05$ : Non significant (NS). 
Our results came in disagreement with a study the study by Foda and Abdel Aal (12), which showed a marked elevation in TNF-a level which was apparent in the Peritoneal fluid of patients with endometriosis, with a higher value in Minimal-Mild than in Moderate-Severe endometriosis $(\mathrm{P}<0.001)$.

In the current study, we found a significant difference in serum Hs-CRP levels in the endometriosis group when compared with the non-endometriosis group $(\mathrm{P}<0.05)$. Serum Hs-CRP levels were also significantly elevated in women with stage 1 and stage 2 endometriosis compared with controls. Comparing serum Hs-CRP levels between women with stage 1 and stage 2 endometriosis, there was also no significant difference ( $>>0.05$; Non significant ).

In agreement with our findings, the study by Foda and Abdel Aal (12) reported that there was a high serum Hs-CRP levels in the endometriosis group when compared with the non-endometriosis group ( $\mathrm{P}<0.001)$. In their study, Moderate - severe endometriosis had significantly higher levels than MinimalModerate endometriosis $(\mathrm{P}<0.001)$. This finding indicated that Hs-CRP cannot be used for early diagnosis of endometriosis. These findings were in agreement with the findings of Lermann et al. (6).

Our results did not agree with the study by Lermann et al. (6) which found no significant difference in CRP and hs-CRP levels in women with histologically confirmed endometriosis in comparison with the other groups of women. Neither hs-CRP nor CRP appeared to be advantageous markers for predicting the presence of endometriosis in that study. There was no association between hs-CRP and CRP levels and the stage of the disease in their study. Their results are in accordance with those reported by Xavier et al. (5), who found no statistically significant differences between women with endometriosis and controls for serum levels of CRP.

In our study, using ROC curve analysis, Serum hsCRP had a cut off point of $1.5 \mathrm{ng} / \mathrm{ml}$ to discriminate cases from controls, with a sensitivity of $85 \%$, specificity of 93.7\% positive predictive value of 87.2 , negative predictive value of 92.6 with diagnostic AUC of 0.83. Serum hsCRP had a cut off point of $4.6 \mathrm{ng} / \mathrm{ml}$ to discriminate cases with stage 1 from cases with stage 2, with a sensitivity of $47.8 \%$, specificity of $91.2 \%$ positive predictive value of 88.0, negative predictive value of 56.4 with diagnostic AUC of 0.65 .

In our study, we found no significant difference between controls and cases regarding peritoneal level of hs-CRP. Similarly, we found no significant difference between controls and cases with stage 1 and stage 2 endometriosis regarding peritoneal level of hs-CRP. Moreover, there was no significant difference between the peritoneal level of hs CRP among cases with stage 1 and cases with stage 2 endometriosis; $\mathrm{P}$ value $>0.05$; Non significant (NS).

In the current study, using ROC curve analysis, Peritoneal TNF had a cut off point of $180 \mathrm{pg} / \mathrm{ml}$ to discriminate cases from controls, with a sensitivity of $87 \%$, specificity of 76.7 $\%$ positive predictive value of 80.9 , negative predictive value of 97.3 with diagnostic AUC of 0.92.Peritoneal TNF had a cut off point of $426 \mathrm{pg} / \mathrm{ml}$ to discriminate cases from with stage 1 from cases with stage 2 , with a sensitivity of $71.7 \%$, specificity of $84.1 \%$ positive predictive value of 97.3 , negative predictive value of 71.1 with diagnostic AUC of 0.86 .

In our study, we analysed the concentrations of plasma cef DNA in the patients and controls and investigated whether the circulating species could be potential biomarkers for developing a non-invasive diagnostic test for the disease.

We found a highly significant difference regarding plasma ccf DNA between controls and cases $(\mathrm{P}<0.01$; highly significant $)$ as well as a significant difference between controls and stage $1 \& 2$ endometriosis. However, the difference between patients with stage 1 and stage 2 was not statistically significant. ( $\mathrm{P}$ value $>0.05$; Non significant (NS).

Our results came in agreement with a study by Zachariah et al. (4), which reported significantly increased concentrations of ccf nDNA in plasma from patients with endometriosis compared with the age-matched controls. It corresponded with the results of different inflammatory diseases presenting elevated ccf nDNA in plasma, which reflects 
the increased frequency of cell-death events in the conditions (7).

The clinical relevance of using the plasma ccf nDNA as a marker to distinguish between the minimal or mild disease and healthy controls was evaluated by ROC analysis. Plasma ccf DNA had a cut off point of 5950 to discriminate cases from controls, with a sensitivity of $97.5 \%$, specificity of $71.2 \%$ positive predictive value of 62.9 , negative predictive value of 98.3 with diagnostic AUC of 0.89. Plasma ccf DNA had a cut off point of 22900 to discriminate cases with stage 1 from cases with stage 2 , with a sensitivity of $69.6 \%$, specificity of $97.1 \%$ positive predictive value of 97.0, negative predictive value of 70.2 with diagnostic AUC of 0.85

\section{CONCLUSION}

Our results showed that serum TNFalfa, serum hs-CRP and plasma ccf DNA are highly reliable biomarkers for screening and early diagnosis of endometriosis, but they can not be used to discriminate between stage I and stage II. On the other hand, peritoneal TNFalpha and peritoneal hs-CRP are non reliable for early diagnosis of endometriosis and can not be used to discriminate between stage I and stage II of endometriosis.

\section{REFERENCES}

1. Boyle KJ and Torrealday S (2008): Benign Gynecologic Conditions. Surgical Clinics of North America;88(2):245-264.

2. Mihalyi A, Gevaert O, Kyama CM et al. (2010): Non-invasive Diagnosis of Endometriosis Based on a Combined Analysis of Six Plasma Biomarkers. Human Reproduction; 25(3):654-664.

3. Kocakoc E, Bhatt $S$ and Dogra VS (2008): Endometriosis. Ultrasound Clinics ;3 (3): 399-414.
4. Zachariah R, Schmid S, Radpour R et al.(2009) : Circulating cell-free DNA as a potential biomarker for minimal and mild endometriosis. Reproductive Bio Medicine Online; 18(3):407-411.

5. Xavier P, Belo L, Beires J et al. (2006) : Serum levels of VEGF and TNF-a and their association with $\mathrm{C}$-reactive protein in patients with endometriosis. Arch Gynecol Obstet ; 273: 227-231.

6. Lermann J, Mueller A, Körber F, et al. (2010): Evaluation of high-sensitivity Creactive protein in comparison with $\mathrm{C}$ reactive protein as biochemical serum markers in women with endometriosis.Fertility and Sterility; 93(7): 2125-2129.

7. Zhong XY, von Muhlenen I, Li Y et al. (2007) : Increased concentrations of antibody-bound circulatory cell-free DNA in rheumatoid arthritis. Clinical Chemistry; 53: 1609-1614.

8. Mcleod BS and Retzloff MG (2010):Epidemiology of endometriosis: an assessment of risk factors. Clin Obstet Gynecol; 53:389-396.

9. Kennedy S, Bergqvist A, Chapron $\mathbf{C}$ et al. (2005): ESHRE guideline for the diagnosis and treatment of endometriosis. Human Reproduction; 20:2698-704.

10. Othman E, Hornung D, Salem HT et al. (2008): Serum cytokines as biomarkers for nonsurgical prediction of endometriosis. European Journal of Obstetrics \& Gynecology and Reproductive Biology; 137: 240-246.

11. Arruda MS, Petta CA, Abrao MS, BenettiPinto CL (2003): Time elapsed from onset of symptoms to diagnosis of endometriosis in a cohort study of Brazilian women. Hum Reprod ; 18:756-9.

12. Foda AA and Abdel Aal IA (2012): Role of some biomarkers in chronic pelvic pain for early detection of endometriosis in infertile women. Middle East Fertility Society Journal ; 17, 187-194 